\title{
Concentration and mobility of copper and zinc in the hypergenic zone of a highly urbanized area
}

\author{
Jerzy J. Małecki ${ }^{1}$ - Monika Kadzikiewicz-Schoeneich ${ }^{2}$ • \\ Marzena Szostakiewicz-Hołownia ${ }^{1}$
}

Received: 11 February 2015/ Accepted: 8 July 2015/Published online: 19 December 2015

(C) The Author(s) 2015. This article is published with open access at Springerlink.com

\begin{abstract}
Common occurrence of copper and zinc in groundwater and their diverse mobility in the environment make these metals sensitive indicators of industrial and municipal pollution of freshwaters. An analysis of the collected data allowed for a description of the factors and processes that induce changes in the concentration of these metals in the soil, rock and groundwater. Sorption, ion exchange and oxidation-reduction processes, dissolution and precipitation of minerals, and reactions involving organic matter significantly affected the mobility of copper and zinc. The study employed hydrogeochemical methods to obtain comprehensive interpretative data. Its results showed that the variability of the composition of exchangeable cations was due to instability of chemical composition of precipitation. Different activities of $\mathrm{Cu}$ and $\mathrm{Zn}$ in the solution introduced into the rocks led to the establishment of new quasi-equilibrium states between the adsorbent and the adsorbate. At very low copper and zinc concentrations in groundwater, zinc was more easily retained in the solid phase, and it was more difficult to extract. In contrast, a laboratory static batch experiment utilizing high concentrations of the elements in the solutions showed their different behavior. The sorption of copper occurred more easily than the sorption of zinc, as evidenced by the study results and the calculated parameters of sorption maximum, binding constant, and degree of surface coverage of the solid phase by adsorbed copper and zinc according to a single Langmuir equation.
\end{abstract}

Marzena Szostakiewicz-Hołownia

marzena.szostakiewicz@uw.edu.pl

1 Faculty of Geology, University of Warsaw, Żwirki i Wigury 93, 02-089 Warsaw, Poland

2 Polish Oil and Gas Company (PGNiG), Kasprzaka 25, 01-224 Warsaw, Poland
Keywords Vadose zone - Saturated zone - Copper . Zinc $\cdot$ Intensity of migration $\cdot$ Sorption parameters

\section{Introduction}

Vadose zone is the zone of the most intense interactions between infiltrating rainwater, soil framework and gas phase in the rock pores. A number of processes and reactions affect the concentration of solutes in percolating water, which is ultimately manifested by changes in water chemistry in the saturation zone (Małecki 1995; Tindall et al. 1999; Kadzikiewicz-Schoeneich and Malecki 2002; Kadzikiewicz-Schoeneich et al. 2005; Augustin and Viero 2012).

Zinc and copper are elements that accurately document the effects of industrial and municipal pollution. Their widespread occurrence in groundwater and diverse mobility in the environment make these metals sensitive indicators of freshwater pollution. Therefore, the identification of processes and reactions determining the variability of $\mathrm{Cu}$ and $\mathrm{Zn}$ concentrations in the zone of shallow groundwater circulation is extremely important in assessing the condition of the environment and in forecasting its transformation (Appelo and Postma 1999; Fetter 1999).

Zinc and copper are among water migrants with a high migration contrast. The mobility of zinc and copper depends on the properties of both the solid phase and the solution. In the weathering zone under oxidizing conditions, easy solubility of zinc sulfates facilitates an intense migration of this metal, which becomes one of the most mobile water migrants (Ajwa and Tabatabai 1997). A decrease in zinc activity is a result of both a formation of metallo-organic complexes and an increase in ionic strength of the solution (Diatta and Kociałkowski 1998). 
The mobility of copper is much lower; it is classified as poorly mobile element. In soils, copper is strongly bound by organic matter and clay minerals (McLaren et al. 1981; Rashad et al. 2014). The mobility of copper is also limited by carbonates, silica, iron and manganese oxides. A frequent phenomenon is an immobilization of copper ions by copper precipitation from a solution in the form of sulfates, sulfides and carbonates (McLaren et al. 1983).

The bonds of $\mathrm{Zn}^{2+}$ and $\mathrm{Cu}^{2+}$ by the solid phase are very complex. They occur mainly through the adsorption and formation of salts, and through the creation of chelated and complex connections. The amount of zinc and copper adsorbed by soil and rock components under equilibrium conditions depends basically on the content of organic matter, clay minerals and metal oxides and hydroxides (Stumm and Morgan 1981; Ross 1994; Arias et al. 2005).

\section{Study description}

The main aim of the study was to determine the content and mobility of copper and zinc in the soils and groundwater in urban areas exposed to strong anthropogenic pressure. Identification of processes occurring in the soil, rock and groundwater environments would help to develop geochemical models explaining the reactions between the solid, liquid and gas phases with particular emphasis on the presence of copper and zinc. A thorough analysis was performed on the results of the observations carried out at a research station of the Faculty of Geology, University of Warsaw, in the years 2000-2004. The research site was located almost in the center of Warsaw, the capital of Poland, next to a busy road connecting the airport with the historical and business center (Fig. 1).

The subsurface zone (Fig. 2) consists of made grounds of variable thickness from 0.5 to over $1 \mathrm{~m}$ : rubble mixed with sandy sediments. Below, there are sandy silts with a thickness of approximately $0.8 \mathrm{~m}$ and a layer of argillaceous sand $1.3 \mathrm{~m}$ in thickness. These sediments are separated from glacial tills of the Middle Polish Glaciation (Mazovian-Podlasian Stadial) by a thin layer of white finegrained sands, $0.5 \mathrm{~m}$ thick. The complex of glacial tills is $2.3 \mathrm{~m}$ thick and is underlain by sandy deposits: $1.6-\mathrm{m}$-thick fine sands resting upon silty sands with a thickness of $1.8 \mathrm{~m}$. The silty sands are an aquifer with the water table found at an average depth of $7.74 \mathrm{~m}$ b.g.l. (elevation $104.76 \mathrm{~m}$ a.s.l.) (Kadzikiewicz-Schoeneich et al. 2005).

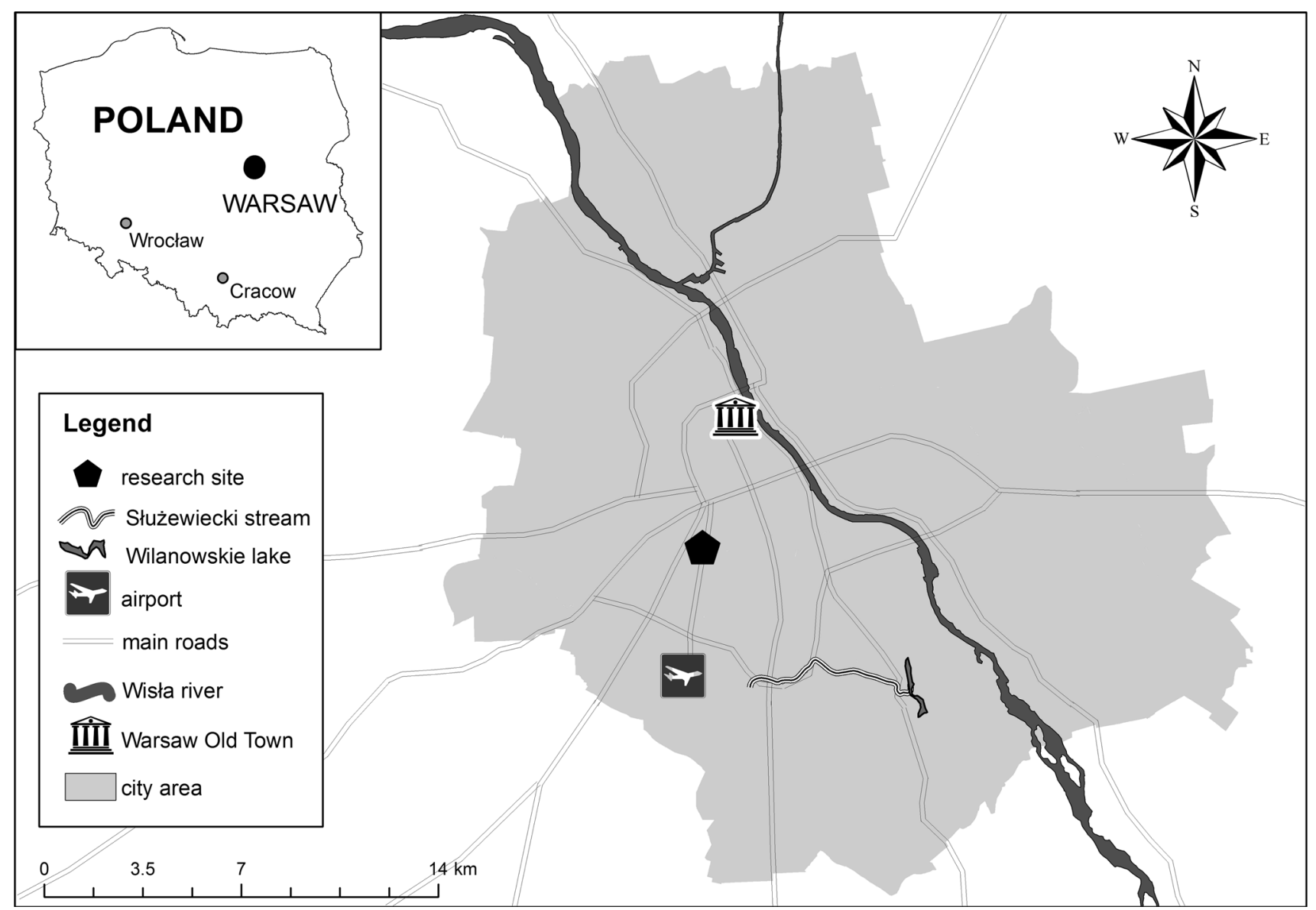

Fig. 1 Location of the research site 


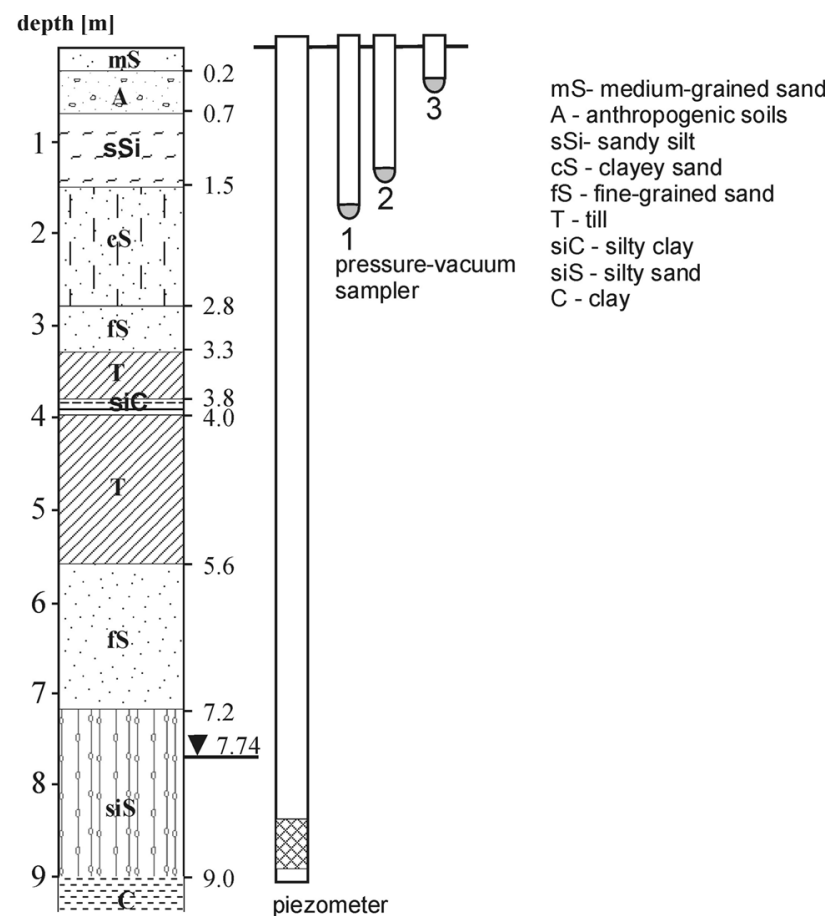

Fig. 2 Lithological section and distribution of wells for hydrochemical sampling

Soil and rock samples for laboratory tests were taken from each individual, lithologically distinct layer of the section. Precipitation amount was measured using a rain gauge. Groundwater from the vadose zone was monitored by pressure-vacuum samplers installed at three depths $(0.47,1.43$ and $1.83 \mathrm{~m})$. Groundwater from the saturation zone was monitored by a piezometer screened between 8.4 and $8.9 \mathrm{~m} \mathrm{b.g.l}$. These measuring devices were made of inert material that did not react with water.

\section{Methods}

The study included the following activities: (1) daily measurements of the depth to the groundwater table and air temperature, (2) precipitation measurements after each rain event, (3) monitoring of rainwater and groundwater for the analysis of physicochemical parameters of water (temperature, $\mathrm{pH}$, oxidation-reduction potential $\mathrm{Eh}$ and electrical conductivity EC), (4) determination of macro- and microcomponents of water and (5) identification of the solid phase composing the soil and rock framework to determine the physicochemical parameters and properties that affect the migration of constituents dissolved in water, including sorption parameters of the solid phase in the aquifer (Kociałkowski et al. 1999).

Detailed investigations were carried out on the deposits down to a depth of $4 \mathrm{~m}$, eliminating the effect of water flowing laterally from other drainage zones. Qualitative X-ray structural analyses of rock samples and X-ray diffraction analyses were performed to determine the content of clay minerals.

The analyses of soils and rocks included determination of the content of $\mathrm{Fe}, \mathrm{Mn}, \mathrm{Al}, \mathrm{Cu}$ and $\mathrm{Zn}$ oxides using the methods of McLaren and Crawford (1973) and Grzebisz et al. (1997). The content of exchangeable cations was determined using the Mehlich method. The initial concentration of copper and zinc in soil/rock $\left(S_{\mathrm{o}}\right)$ was assessed using the Lindsay and Norvell's method and the aqua regia method (Kociałkowski et al. 1999).

\section{Results and discussion}

Results of the solid phase analysis indicated the occurrence of quartz, feldspars, and rare calcite and clay minerals in each lithologically distinct layer (Table 1) (KadzikiewiczSchoeneich et al. 2005).

Two types of clay minerals, kaolinite and beidellite, occurred throughout the whole section (Table 2). In terms of percentage content, beidellite significantly predominated over kaolinite. As showed by granulometric and X-ray diffraction studies, there was an increase in the content of clay minerals with depth. The percentage of clay minerals varied from 1.74 to $46.95 \%$ (Kadzikiewicz-Schoeneich et al. 2005).

A precise determination of clay fraction content is important for developing a geochemical model (Alloway

Table 1 Major minerals composing the soil framework

\begin{tabular}{lll}
\hline Lithology & Depth $(\mathrm{m})$ & Minerals \\
\hline Medium-grained sand & $0.0-0.2$ & Quartz, feldspars, clay minerals, and mica and hydromica group \\
Antropogenic soil & $0.2-0.7$ & Quartz, feldspars, calcite, traces of dolomite, clay minerals, and mica and hydromica group \\
Sandy silt & $0.7-1.5$ & Quartz, feldspars, calcite, clay minerals, and mica and hydromica group \\
Argillaceous sand & $1.5-2.8$ & Quartz, feldspars, mica and hydromica group, clay minerals \\
Fine-grained sand & $2.8-3.3$ & Quartz, feldspars \\
Till & $3.3-3.8$ & Quartz, feldspars, mica and hydromica group, chlorite, kaolinite \\
Silty clay & $3.8-4.0$ & Quartz, feldspars, mica and hydromica group, chlorite, kaolinite, traces of siderite \\
\hline
\end{tabular}


Table 2 Results of X-ray diffraction analysis

\begin{tabular}{|c|c|c|c|}
\hline Lithology & Depth (m) & Constituents & Content $(\%)$ \\
\hline \multirow[t]{4}{*}{ Sandy silt } & \multirow[t]{4}{*}{$0.7-1.5$} & Beidellite $(63.8 \%) \gg$ kaolinite $(36.2 \%)$ & 1.74 \\
\hline & & Organic matter & 0.50 \\
\hline & & Calcite & 0.30 \\
\hline & & Quartz + thermally inactive components & 97.46 \\
\hline \multirow[t]{3}{*}{ Argillaceous sand } & \multirow[t]{3}{*}{$1.5-2.8$} & Beidellite $(73.7 \%) \gg$ kaolinite $(26.3 \%)$ & 9.30 \\
\hline & & Organic matter & 0.13 \\
\hline & & Quartz + thermally inactive components & 90.57 \\
\hline \multirow[t]{4}{*}{ Till } & \multirow[t]{4}{*}{$3.3-3.8$} & Beidellite $(78 \%) \gg$ kaolinite $(22 \%)$ & 29.40 \\
\hline & & Organic matter & 0.30 \\
\hline & & Goethite & 4.30 \\
\hline & & Quartz + thermally inactive components & 66.00 \\
\hline \multirow[t]{4}{*}{ Silty clay } & \multirow[t]{4}{*}{$3.8-4.0$} & Beidellite $(86 \%) \gg$ kaolinite (14\%) & 46.95 \\
\hline & & Organic matter & 0.50 \\
\hline & & Goethite & 4.20 \\
\hline & & Quartz + thermally inactive components & 48.35 \\
\hline
\end{tabular}

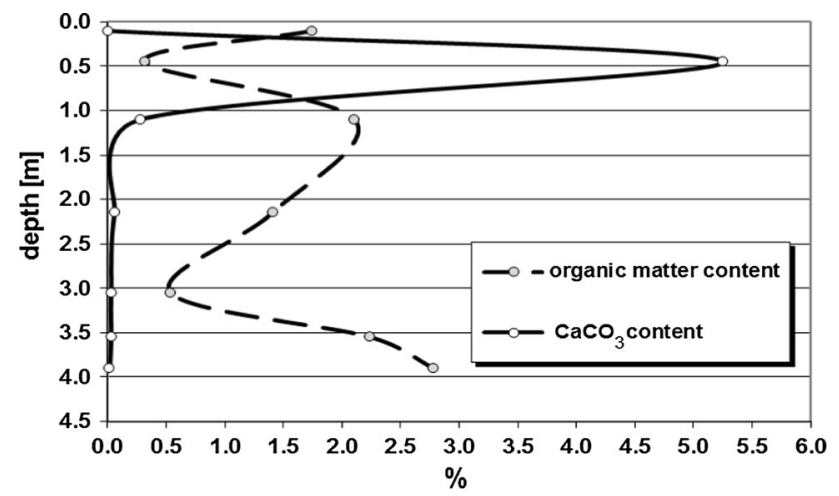

Fig. 3 Content of carbonates and organic matter

1995). This fraction participates in the sorption of heavy metals and thus significantly affects their migration. The balance of aqueous solutions also closely depends on the type of clay minerals in the soil framework (Deutsch 1997).

Rock samples were also tested for carbonate and organic matter content. Significant amounts of carbonates were found in the upper part of the section, in the anthropogenic soil layer at a depth of $0.2-0.7 \mathrm{~m}$ b.g.l. (Fig. 3). The main source of the carbonates was limestone rubble found in the anthropogenic soil. Minor amounts of carbonates $(0.02-0.06 \%)$ were present in the lower part of the section, in the deposits containing significant amounts of clay fraction (Fig. 3). Carbonate content in the solid phase is of great importance for hydrogeochemical interpretations. In the case of infiltrating waters with a relatively low $\mathrm{pH}$, carbonates act as a buffer. Therefore, in the deposits containing certain amounts of carbonates, the impact of, e.g., acidic precipitation is much less noticeable than in those without this component. It should also be mentioned that $\mathrm{pH}$ of the

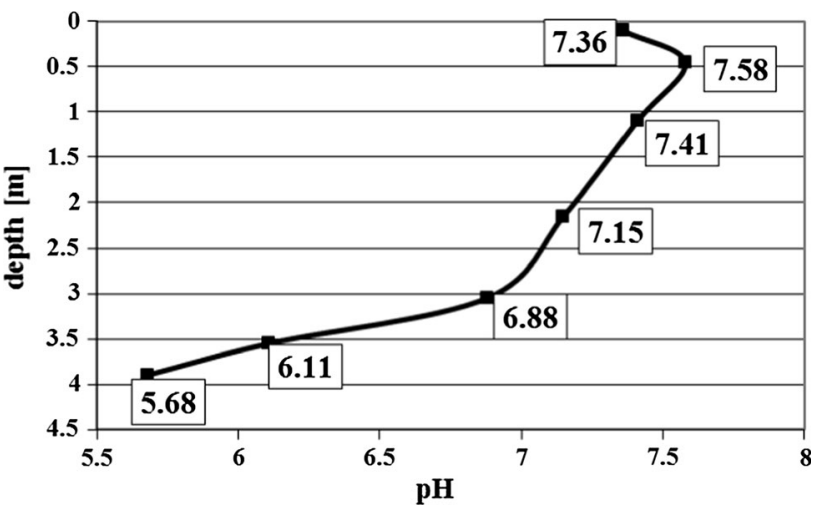

Fig. $4 \mathrm{pH}$ values of the soils and rocks

environment forces the migration of elements, e.g., heavy metals, including copper and zinc (McFarlane et al. 1983).

The content of organic matter in the section varied from 0.32 to $2.78 \%$, with high levels in the subsurface layer $(1.75 \%)$. Beneath, in the anthropogenic soil, the content of organic matter rapidly decreased $(0.32 \%)$ and then increased in sandy silts $(2.11 \%)$, gradually decreased in argillaceous sands $(1.41 \%)$ and in fine-grained sands $(0.54 \%)$, and finally increased again in tills $(2.24 \%)$ and sandy clays $(2.78 \%)$ (Fig. 3$)$.

$\mathrm{pH}$ values of the soils and rocks, determined with $0.01 \mathrm{~mol} / 1 \mathrm{CaCl}_{2}$ method, varied along the section from slightly alkaline in the subsurface zone (7.36) to slightly acidic in its lower part (5.68) (Fig. 4).

Organic matter is involved in the sorption processes of heavy metals, along with the solid phase components such as clay minerals, and oxides and hydroxides of iron, manganese and aluminum. In addition, it may participate in organo-mineral associations with clay minerals and form 
Table 3 The contents of exchangeable cations

\begin{tabular}{|c|c|c|c|c|c|c|c|c|}
\hline \multirow[t]{3}{*}{ Lithology } & \multirow[t]{3}{*}{ Depth (m) } & \multicolumn{7}{|c|}{ Exchangeable cation } \\
\hline & & \multicolumn{4}{|l|}{$\mathrm{S}$} & \multirow{2}{*}{$\begin{array}{l}\mathrm{Hw}^{+} \\
\left(\mathrm{cmol}_{+} / \mathrm{kg}\right)\end{array}$} & \multirow{2}{*}{$\begin{array}{l}\mathrm{Hw}^{+}+\mathrm{S} \\
\left(\mathrm{cmol}_{+} / \mathrm{kg}\right)\end{array}$} & \multirow{2}{*}{$\begin{array}{l}\mathrm{CEC}-\mathrm{Ba}^{2-} \\
\left(\mathrm{cmol}_{+} / \mathrm{kg}\right)\end{array}$} \\
\hline & & $\begin{array}{l}\mathrm{Ca}^{2+} \\
\left(\mathrm{cmol}_{+} / \mathrm{kg}\right)\end{array}$ & $\begin{array}{l}\mathrm{Mg}^{2+} \\
\left(\mathrm{cmol}_{+} / \mathrm{kg}\right)\end{array}$ & $\begin{array}{l}\mathrm{K}^{+} \\
\left(\mathrm{cmol}_{+} / \mathrm{kg}\right)\end{array}$ & $\begin{array}{l}\mathrm{Na}^{+} \\
\left(\mathrm{Cmol}_{+} / \mathrm{kg}\right)\end{array}$ & & & \\
\hline Medium-grained sand & $0.0-0.2$ & 10.02 & 0.58 & 0.61 & 0.08 & n.s. & 11.29 & 14.01 \\
\hline Antropogenic soil & $0.2-0.7$ & 9.97 & 0.61 & 0.42 & 0.09 & n.s. & 11.09 & 18.68 \\
\hline Sandy silt & $0.7-1.5$ & 9.29 & 0.83 & 0.29 & 0.29 & n.s. & 10.07 & 7.94 \\
\hline Argillaceous sand & $1.5-2.8$ & 6.12 & 1.01 & 0.35 & 0.43 & 0.341 & 8.25 & 6.02 \\
\hline Fine-grained sand & $2.8-3.3$ & 3.51 & 0.47 & 0.31 & 0.33 & 0.018 & 4.64 & 4.46 \\
\hline Till & $3.3-3.8$ & 11.44 & 2.35 & 0.61 & 0.54 & 0.563 & 15.50 & 19.46 \\
\hline Silty clay & $3.8-4.0$ & 15.09 & 2.84 & 0.83 & 0.92 & 0.951 & 20.63 & 23.59 \\
\hline
\end{tabular}

$S$ sum of exchangeable cations $\left(\mathrm{Ca}^{2+}, \mathrm{Mg}^{2+}, \mathrm{K}^{+}, \mathrm{Na}^{+}\right)$. n.s. not detected

complex compounds with iron, aluminum, manganese and other elements. From among various heavy metals, copper and zinc are those mostly sorbed by organic matter, as showed by Lead et al. (1999) and Covelo et al. (2004).

$\mathrm{pH}$ pattern of the soil-rock environment was largely affected by the carbonate content that was relatively high in the subsurface zone and decreased down the section. Determination of $\mathrm{pH}$ of soil and rock is important for hydrogeochemical interpretations, as it allows for the evaluation of the direction and nature of the sorption processes. A significant part of the research was focused on the determination of exchangeable cations in the solid phase, as well as of a general cation exchange capacity. The highest cation exchange capacity (CEC), specified from the amount of $\mathrm{Ba}^{2+}$, as well as from the sum of alkaline and acidic cations, was found in the subsurface layer and in the till and silty clay layer. These deposits were rich in both organic matter and clay fraction.

The most common element among the exchangeable cations was calcium $\left(\mathrm{Ca}^{2+}\right)$. Its concentration in the subsurface layer was $10.2 \mathrm{cmol}_{+} / \mathrm{kg}$ and slightly decreased down to a depth of $2.8 \mathrm{~m} \mathrm{b.g.l.,}$ where it reached its minimum of $3.51 \mathrm{cmol}_{+} / \mathrm{kg}$. The amount of exchangeable $\mathrm{Ca}^{2+}$ rapidly increased downward from a depth of $3.3 \mathrm{~m}$ b.g.l. in tills $\left(11.44 \mathrm{cmol}_{+} / \mathrm{kg}\right)$ and clays $\left(15.09 \mathrm{cmol}_{+} / \mathrm{kg}\right)$ (Table 3) (Kadzikiewicz-Schoeneich et al. 2005).

The measurements showed much lower contents of exchangeable $\mathrm{K}^{+}, \mathrm{Na}^{+}$and $\mathrm{Mg}^{2+}$ than $\mathrm{Ca}^{2+}$. The contents of exchangeable magnesium and sodium increased with depth, except for the fine-grained sand layer $(2.8-3.3 \mathrm{~m}$ b.g.l.). The amount of exchangeable magnesium varied from $0.58 \mathrm{cmol}_{+} / \mathrm{kg}$ in the subsurface zone to $2.84 \mathrm{cmol}_{+} /$ $\mathrm{kg}$ in the lower part of the section. Sodium concentrations were still lower than the concentrations of magnesium, amounting to $0.08 \mathrm{cmol}_{+} / \mathrm{kg}$ in the subsurface zone, and $0.92 \mathrm{cmol}_{+} / \mathrm{kg}$ at a depth of $3.8 \mathrm{~m} \mathrm{b.g.l.} \mathrm{(Table} \mathrm{3)} \mathrm{(Kad-}$ zikiewicz-Schoeneich et al. 2005).

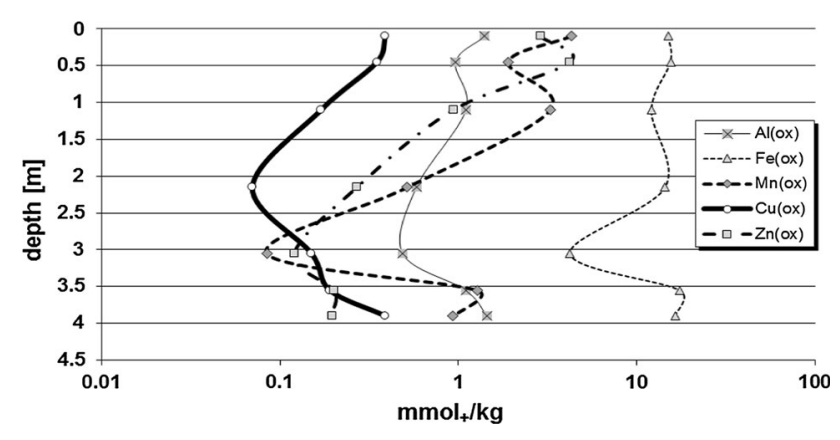

Fig. 5 Changes in the content of amorphous forms of $\mathrm{Al}(\mathrm{ox}), \mathrm{Fe}(\mathrm{ox})$, $\mathrm{Mn}(\mathrm{ox}), \mathrm{Cu}(\mathrm{ox})$ and $\mathrm{Zn}(\mathrm{ox})$

The content of exchangeable potassium decreased down the section to a depth of $3.3 \mathrm{~m}$ b.g.l. from 0.61 to $0.29 \mathrm{cmol}_{+} /$ $\mathrm{kg}$. Below, in the till layer $\left(0.61 \mathrm{cmol}_{+} / \mathrm{kg}\right)$ and the silty clay layer $\left(0.83 \mathrm{cmol}_{+} / \mathrm{kg}\right)$, the exchangeable potassium content increased (Table 3). Exchangeable hydrogen $\left(\mathrm{Hw}^{+}\right)$, affecting the acidity of soils and rocks, was not detected in the upper part of the section down to a depth of $1.5 \mathrm{~m}$. From this depth on, its amount increased downward from 0.341 to 0.951 $\mathrm{cmol}_{+} / \mathrm{kg}$ (Table 3) (Kadzikiewicz-Schoeneich et al. 2005). The above-presented changes in $\mathrm{pH}$ of the soils and rocks can largely be associated with the occurrence of exchangeable cations with specified acidic or alkaline nature. Weakly alkaline $\mathrm{pH}$ observed in the upper part of the section was due to both the presence of basic cations and the absence of exchangeable hydrogen. The increase in $\mathrm{H}_{\mathrm{w}}^{+}$content with depth changed $\mathrm{pH}$ of the rocks toward slightly acidic.

In the zone of shallow groundwater circulation, a significant role in the sorption processes, in addition to the content of organic matter and clay fraction, is played by amorphous forms of iron, manganese and aluminum (Fig. 5).

Iron oxides were the most common compounds along the entire section. Their content was several times greater 
than the content of the remaining oxides. Fe(ox) concentration showed small fluctuations ranging from 12.089 to $17.491 \mathrm{mmol}_{+} / \mathrm{kg}$ (Fig. 4). Aluminum oxides also revealed a relatively constant level varying between 0.964 and $1.449 \mathrm{mmol}_{+} / \mathrm{kg}$ (Fig. 5). The greatest variability between the individual lithological layers was observed for manganese oxide. A considerable amount of $\mathrm{Mn}(\mathrm{ox})$ in the subsurface layer $\left(4.285 \mathrm{mmol}_{+} / \mathrm{kg}\right)$ decreased to $1.906 \mathrm{mmol}_{+} / \mathrm{kg}$ at a depth of $0.2-0.7 \mathrm{~m} \mathrm{b.g.1}$. in the anthropogenic soil and then increased again in the sandy silt layer to $3.281 \mathrm{mmol}_{+} / \mathrm{kg}$. Beneath a depth of $1.5 \mathrm{~m}$, there was a very rapid decrease in $\mathrm{Mn}(\mathrm{ox})$ concentration to $0.518 \mathrm{mmol}_{+} / \mathrm{kg}$, and beneath a depth of $2.8 \mathrm{~m}$ - even to $0.085 \mathrm{mmol}_{+} / \mathrm{kg}$. Mn concentration in argillaceous deposits increased up to $1.279 \mathrm{mmol}_{+} / \mathrm{kg}$, whereas in the silty clay layer it was $0.935 \mathrm{mmol}_{+} / \mathrm{kg}$ (Fig. 5).

The content of zinc oxide decreased with depth. High concentration of $\mathrm{Zn}(\mathrm{ox})$ in the most shallow zone was associated with pollution migration from the surface and accumulation of this metal in anthropogenic soils. In the subsurface zone (soil), its concentration was $2.891 \mathrm{mmol}_{+} /$ $\mathrm{kg}$, and in the anthropogenic soils it was as high as $4.233 \mathrm{mmol}_{+} / \mathrm{kg}$. The lowest content of $\mathrm{Zn}(\mathrm{ox})$ was found in fine-grained sands at the depth of $2.8-3.3 \mathrm{~m} \mathrm{b.g.1}$ $\left(0.121 \mathrm{mmol}_{+} / \mathrm{kg}\right)$. In the tills below (3.3-3.8 $\mathrm{m}$ b.g.1.), the content of $\mathrm{Zn}(\mathrm{ox})$ was higher and amounted to $0.201 \mathrm{mmol}_{+} / \mathrm{kg}$ (Fig. 5).

High content of zinc oxide in the subsurface of the investigated section was due to the proximity of a major road connecting the airport with financial and historical center of the city and the remnants of urban infrastructure destroyed during the Second World War (Fig. 1).

The authors are aware that the concentrations of metals found in the zone of anthropogenic soils may be of random character, but they are similar to the findings of other studies involving Warsaw and other large Polish cities. For example, maximum content of $\mathrm{Zn}(\mathrm{ox})$ measured for the green areas of
Warsaw was $3.66 \mathrm{mmol} / \mathrm{kg}$ (Czarnowska 1999), and slightly higher concentration amounting to $5.63 \mathrm{mmol} / \mathrm{kg}$ was found in the valley of the Służewiec Stream in Warsaw (Bojakowska et al. 2012). In Kraków, the maximum concentration of zinc oxide in green areas was $4.95 \mathrm{mmol} / \mathrm{kg}$ (Szwalec and Mundała 2012), but in allotment gardens in Wrocław it was as high as $25.84 \mathrm{mmol} / \mathrm{kg}$ (Kabała et al. 2009).

A higher content of copper oxides was associated with the deposits containing either organic matter or a substantial part of clay fraction. In the subsurface zone, $\mathrm{Cu}(\mathrm{ox})$ concentration was $0.39 \mathrm{mmol}_{+} / \mathrm{kg}$, and it decreased with depth down to the till layer $\left(0.19 \mathrm{mmol}_{+} / \mathrm{kg}\right)$. In the silty clay, $\mathrm{Cu}$ concentration was higher again $\left(0.39 \mathrm{mmol}_{+} / \mathrm{kg}\right)$ (Fig. 5).

In order to fully determine copper and zinc content in the solid phase by various methods, total concentration of these metals was measured and it was defined as an initial concentration $S_{\mathrm{o}}$ (Table 4). While analyzing the study results (Table 4) (Kadzikiewicz-Schoeneich and Malecki 2002), it should be pointed out that the applied methods based on using diethylene triamine pentaacetic acid (DTPA) and aqua regia (AR) were characterized by different extraction capacities (Lindsay and Norvell 1978). However, proportionally to the extraction capacity, the amount of extracted copper and zinc depended primarily on their concentrations in the solid phase (Stewart 1991). The initial zinc concentration in the soils and rocks confirmed previous findings, including determinations of, e.g., $\mathrm{Zn}(\mathrm{ox})$.

The highest $\mathrm{Zn}$ content was found in the soils and anthropogenic deposits. The vertical section showed a constant decrease in $\mathrm{Zn}$ content down to the fine sand layer (2.8-3.3 m b.g.1.), where its content was the lowest. An increase in $\mathrm{Zn}$ content was observed in the clays and silty clays. The same trend was noticeable in the case of copper, but its content was considerably lower than that of zinc.

The initial concentrations of copper and zinc $\left(S_{\mathrm{o}}\right)$ were obtained by the batch experiment that used the sorption
Table 4 Initial concentration $\left(S_{\mathrm{o}}\right)$ of copper and zinc

\begin{tabular}{|c|c|c|c|c|c|}
\hline \multirow[t]{3}{*}{ Lithology } & \multirow[t]{3}{*}{ Depth (m) } & \multicolumn{4}{|c|}{ Initial concentration in solid phase } \\
\hline & & \multicolumn{2}{|l|}{$\mathrm{Zn}$} & \multicolumn{2}{|l|}{$\mathrm{Cu}$} \\
\hline & & $\begin{array}{l}S_{\mathrm{o}}-\mathrm{DTPA} \\
\left(\mathrm{mmol}_{+} / \mathrm{kg}\right)\end{array}$ & $\begin{array}{l}S_{\mathrm{o}}-\mathrm{AR} \\
\left(\mathrm{mmol}_{+} / \mathrm{kg}\right)\end{array}$ & $\begin{array}{l}S_{\mathrm{o}}-\mathrm{DTPA} \\
\left(\mathrm{mmol}_{+} / \mathrm{kg}\right)\end{array}$ & $\begin{array}{l}S_{\mathrm{o}}-\mathrm{AR} \\
\left(\mathrm{mmol}_{+} / \mathrm{kg}\right)\end{array}$ \\
\hline Medium-grained sand & $0.0-0.2$ & 0.990 & 4.770 & 0.200 & 0.630 \\
\hline Antropogenic soil & $0.2-0.7$ & 1.320 & 7.770 & 0.170 & 0.640 \\
\hline Sandy silt & $0.7-1.5$ & 0.205 & 1.760 & 0.060 & 0.200 \\
\hline Argillaceous sand & $1.5-2.8$ & 0.017 & 0.500 & 0.010 & 0.270 \\
\hline Fine-grained sand & $2.8-3.3$ & 0.009 & 0.170 & 0.010 & 0.051 \\
\hline Till & $3.3-3.8$ & 0.053 & 1.580 & 0.070 & 0.540 \\
\hline Silty clay & $3.8-4.0$ & 0.030 & 1.890 & 0.070 & 0.500 \\
\hline
\end{tabular}

$S_{\mathrm{o}}-\mathrm{DTPA}$ - Lindsay and Norvell's method, $S_{\mathrm{o}}-\mathrm{AR}$ - aqua regia method 
isotherm according to a single Langmuir equation. So it was determined by DTPA and aqua regia methods (Langmuir 1997).

Single Langmuir equation:

$C / S=\left(1 / \alpha_{\max } \cdot b\right)+\left(C / \alpha_{\max }\right)$

where $S$ amount of the element retained in the soil $\left(\mathrm{mmol}_{+/} \mathrm{kg}\right), C$ equilibrium concentration of the element in the solution $\left(\mathrm{mmol}_{+} / \mathrm{dm}^{3}\right), \alpha_{\max }$ sorption maximum $\left[\mathrm{mmol}_{+} / \mathrm{kg}\right]$ and $b$ binding coefficient $\left(\mathrm{dm}^{3} / \mathrm{mmol}_{+}\right)$. The value of $S$ for each measurement was calculated according to the equation:

$S=(C o-C) \cdot(V / w)+S_{\mathrm{o}}$

where $C o$ initial concentration in the solution $\left(\mathrm{mmol}_{+} /\right.$ $\mathrm{dm}^{3}$ ), $C$ equilibrium concentration of the element in the solution $\left(\mathrm{mmol}_{+} / \mathrm{dm}^{3}\right), V$ solution volume $\left(\mathrm{cm}^{3}\right), w$ weight of rock/soil sample $(\mathrm{g})$ and $S_{\mathrm{o}}$ initial concentration of the element in the soil/rock $\left(\mathrm{mmol}_{+} / \mathrm{kg}\right)$.

Sorption parameters were determined from the linear regression method, which was the basis for the determination of $\alpha_{\max }$ and $b$ values, and from the spreadsheet $M B C$ (maximum buffering capacity $\left[\mathrm{dm}^{3} / \mathrm{kg}\right]$ ).

For each depth interval, we also calculated $Q$ surface coverage degree [\%], i.e., the degree of soil saturation with $\mathrm{Cu}$ and $\mathrm{Zn}$ ions.

In the lithological section, the sorption process occurred in three sorption centers represented by the clay fraction, organic matter and amorphous forms of $\mathrm{Fe}, \mathrm{Al}$ and $\mathrm{Mn}$. The input data and the calculated sorption parameters for $\mathrm{Cu}$ and $\mathrm{Zn}$ are shown in Tables 5 and 6.

The maximum sorption values $\alpha_{\max }$ determined for copper allowed for a conclusion that the deposits were characterized by high sorption potential. This referred particularly to the subsurface zone from 0 to approximately $1.5 \mathrm{~m}$ below ground level. Below, there was a distinct decrease in sorption potential of the rocks in relation to this element, despite continuously high $\alpha_{\max }$ values. Even the tills and silty clays did not exhibit such a high sorption potential. The reason for the decrease in the maximum sorption of copper was a considerable saturation of the sorption complex with other cations, as evidenced by the comparison with the values of total cation exchange capacity (Table 3 ).

The zinc sorption parameters of the soils and rocks indicated that zinc was less effectively absorbed than copper. Despite similar concentrations of these elements used in the test solutions, zinc exhibited much lower binding potential to the solid phase than copper. It was evidenced from, e.g., the values of maximum sorption $\alpha_{\max }$, which were significantly lower in the case of zinc. For example, $\alpha_{\max }$ of copper in the rock sample from a depth of $3.3-3.8 \mathrm{~m}$ was approximately $33 \mathrm{mmol}_{+} / \mathrm{kg}$, while $\alpha_{\max }$ of zinc in the same sample was $7.5 \mathrm{mmol}_{+} / \mathrm{kg}$. The initial zinc concentrations determined by Lindsay and Norvell's method and aqua regia method were different. In the case of copper, the differences in the initial concentrations obtained by these two methods were not as high as in the case of zinc. Different amounts of extracted zinc, depending on the method used, indicated that it was more strongly bound to the solid phase, and only the solutions with high dissolution capacity were capable of bringing it into the solution.

The initial values of $S_{\mathrm{o}}$, adopted for the calculation of sorption parameters of copper and zinc, and obtained by the two methods, did not significantly affect the diversity of maximum sorption values $\alpha_{\max }$ or the other parameters. According to the authors, this added credibility to the calculation scheme used. Figure 6 shows the concentration of copper and zinc in the solid phase, and the values of maximum sorption obtained for copper and zinc from Langmuir isotherm-based calculations, as compared to the total cation exchange capacity of the tested soils and rocks.

The initial copper concentration $S_{\mathrm{o}}$ in the soils and rocks was higher in the subsurface zone (soil) and in the deposits occurring below $3.3 \mathrm{~m}$, containing significant quantities of clay fraction. The soil layer, rich in organic matter and amorphous forms of iron, manganese and aluminum, was capable of sorbing significant amounts of copper.

The initial zinc concentration in the solid phase of the section was much higher than that of copper. The content of both zinc and copper was higher in the subsurface zone and at depths greater than $3.3 \mathrm{~m}$ (till and silty clay). However, the maximum sorption values were lower for zinc than for copper. They were also lower than the values of total cation exchange capacity along the section. This was the basis for a conclusion that, at certain physicochemical parameters of the section, zinc exhibited lower ability to bind to the solid phase than copper, whereby it became a much more mobile migrant in groundwater.

The aim of the study was to determine the conditions of zinc and copper migration for the assessment of interaction between the solid phase and the solution. Therefore, the necessary data also included physicochemical parameters of precipitation and groundwater. Changes in the chemistry of precipitation are to high extent controlled by anthropogenic factors (Kadzikiewicz-Schoeneich et al. 2001). In the section under study, atmospheric precipitation was the main source of metals, including copper and zinc. Therefore, it was necessary to determine $\mathrm{Zn}$ and $\mathrm{Cu}$ pollution loads brought to the soils and rocks.

The amount of particulate matter in the air over urban areas is much greater than in the countryside. Particulates affect the supply of increased quantities of mineral components into the atmosphere, including copper and zinc that finally enrich atmospheric precipitation and, indirectly, 
Table 5 Sorption parameters of copper, determined in the soils and rocks, for the values of $S_{\mathrm{o}}$ calculated using DTPA and aqua regia methods

\begin{tabular}{|c|c|c|c|c|c|c|c|c|c|}
\hline \multirow[t]{2}{*}{ Depth (m) } & \multirow[t]{2}{*}{$\mathrm{Co}\left(\mathrm{mmol}_{+} / \mathrm{dm}^{3}\right)$} & \multirow[t]{2}{*}{$\mathrm{C}\left(\mathrm{mmol}_{+} / \mathrm{dm}^{3}\right)$} & \multicolumn{2}{|c|}{$\mathrm{S}\left(\mathrm{mmol}_{+} / \mathrm{kg}\right)$} & \multicolumn{2}{|l|}{$Q \%$} & \multicolumn{3}{|c|}{ Sorption parameters } \\
\hline & & & DTPA & $\mathrm{AR}$ & DTPA & $\mathrm{AR}$ & Parameter & DTPA & $\mathrm{AR}$ \\
\hline \multirow[t]{10}{*}{$0.0-0.2$} & 0.20 & 0.003 & 19.95 & 20.38 & 14.16 & 14.47 & $S_{\mathrm{o}}$ & 0.20 & 0.63 \\
\hline & 0.40 & 0.004 & 39.77 & 40.20 & 28.24 & 28.54 & $V$ & 100 & \\
\hline & 0.60 & 0.009 & 59.33 & 59.76 & 42.12 & 42.43 & $W$ & 1 & \\
\hline & 0.80 & 0.037 & 76.50 & 76.93 & 54.32 & 54.62 & $\alpha_{\max }$ & 140,8 & \\
\hline & 1.00 & 0.069 & 93.30 & 93.73 & 66.24 & 66.55 & $b$ & 35.5 & \\
\hline & 1.20 & 0.143 & 105.90 & 106.33 & 75.19 & 75.49 & $\mathrm{MBC}$ & 5000.0 & \\
\hline & 1.40 & 0.278 & 112.40 & 112.83 & 79.80 & 80.11 & Corr. coeff. & 0.994 & \\
\hline & 1.60 & 0.382 & 122.00 & 122.43 & 86.62 & 86.93 & & & \\
\hline & 1.80 & 0.456 & 134.60 & 135.03 & 95.57 & 95.87 & & & \\
\hline & 2.00 & 0.574 & 142.77 & 143.20 & 99.51 & 99.82 & & & \\
\hline \multirow[t]{7}{*}{$0.2-0.7$} & 0.20 & 0.002 & 19.98 & 20.45 & 11.39 & 11.66 & $S_{\mathrm{o}}$ & 0.17 & 0.64 \\
\hline & 0.80 & 0.006 & 79.54 & 80.01 & 45.34 & 45.61 & $V$ & 100 & \\
\hline & 1.00 & 0.012 & 98.94 & 99.41 & 56.40 & 56.66 & $w$ & 1 & \\
\hline & 1.20 & 0.034 & 116.77 & 117.24 & 66.56 & 66.83 & $\alpha_{\max }$ & 175,4 & \\
\hline & 1.40 & 0.063 & 133.87 & 134.34 & 76.31 & 76.57 & $b$ & 81.4 & \\
\hline & 1.80 & 0.153 & 164.87 & 165.34 & 93.98 & 94.24 & $\mathrm{MBC}$ & 14285,7 & \\
\hline & 2.00 & 0.316 & 168.57 & 169.04 & 96.08 & 96.35 & Corr. coeff. & 0.999 & \\
\hline \multirow[t]{10}{*}{$0.7-1.5$} & 0.05 & 0.008 & 4.26 & 4.40 & 6.30 & 6.47 & $S_{\mathrm{o}}$ & 0.06 & 0.20 \\
\hline & 0.10 & 0.007 & 9.36 & 9.50 & 13.85 & 13.97 & $V$ & 100 & \\
\hline & 0.15 & 0.008 & 14.26 & 14.40 & 21.10 & 21.17 & $w$ & 1 & \\
\hline & 0.25 & 0.014 & 23.66 & 23.80 & 35.02 & 34.99 & $\alpha_{\max }$ & 68.0 & \\
\hline & 0.30 & 0.016 & 28.46 & 28.60 & 42.12 & 42.04 & $b$ & 18.5 & \\
\hline & 0.50 & 0.095 & 40.56 & 40.70 & 60.03 & 59.83 & $\mathrm{MBC}$ & 1258.0 & \\
\hline & 0.75 & 0.227 & 52.36 & 52.50 & 77.49 & 77.18 & Corr. coeff. & 0.997 & \\
\hline & 1.00 & 0.411 & 58.98 & 59.12 & 87.29 & 86.91 & & & \\
\hline & 1.50 & 0.899 & 60.16 & 60.30 & 89.04 & 88.64 & & & \\
\hline & 2.00 & 1.330 & 67.06 & 67.20 & 99.25 & 98.78 & & & \\
\hline \multirow[t]{10}{*}{$1.5-2.8$} & 0.15 & 0.014 & 6.81 & 7.07 & 29.21 & 30.05 & $S_{\mathrm{o}}$ & 0.01 & 0.27 \\
\hline & 0.20 & 0.024 & 8.81 & 9.07 & 37.79 & 38.55 & $V$ & 50 & \\
\hline & 0.30 & 0.067 & 11.66 & 11.92 & 50.02 & 50.66 & $w$ & 1 & \\
\hline & 0.50 & 0.184 & 15.81 & 16.07 & 67.82 & 68.30 & $\alpha_{\max }$ & 23.3 & 23.5 \\
\hline & 0.60 & 0.267 & 16.66 & 16.92 & 71.47 & 71.91 & $b$ & 14.3 & 14.7 \\
\hline & 0.80 & 0.430 & 18.51 & 18.77 & 79.41 & 79.77 & $\mathrm{MBC}$ & 333.1 & 345.5 \\
\hline & 1.00 & 0.577 & 21.16 & 21.42 & 90.78 & 91.04 & Corr. coeff. & 0.999 & 0.999 \\
\hline & 1.20 & 0.780 & 21.01 & 21.27 & 90.13 & 90.40 & & & \\
\hline & 1.50 & 1.060 & 22.01 & 22.27 & 94.42 & 94.65 & & & \\
\hline & 2.00 & 1.550 & 22.51 & 22.77 & 96.57 & 96.77 & & & \\
\hline \multirow[t]{10}{*}{$2.8-3.3$} & 0.15 & 0.013 & 4.12 & 4.16 & 37.66 & 37.91 & $S_{\mathrm{o}}$ & 0.01 & 0.051 \\
\hline & 0.20 & 0.037 & 4.90 & 4.94 & 44.79 & 45.02 & $V$ & 30 & \\
\hline & 0.30 & 0.082 & 6.54 & 6.58 & 59.87 & 60.05 & $w$ & 1 & \\
\hline & 0.50 & 0.228 & 8.16 & 8.20 & 74.68 & 74.81 & $\alpha_{\max }$ & 10.9 & 11.0 \\
\hline & 0.60 & 0.289 & 9.33 & 9.37 & 85.38 & 85.47 & $b$ & 19.1 & 19.4 \\
\hline & 0.80 & 0.490 & 9.30 & 9.34 & 85.10 & 85.20 & $\mathrm{MBC}$ & 208.2 & 213.4 \\
\hline & 1.00 & 0.670 & 9.90 & 9.94 & 90.59 & 90.66 & Corr. coeff. & 0.999 & 0.999 \\
\hline & 1.20 & 0.850 & 10.50 & 10.54 & 96.07 & 96.13 & & & \\
\hline & 1.50 & 1.140 & 10.80 & 10.84 & 98.81 & 98.86 & & & \\
\hline & 2.00 & 1.650 & 10.50 & 10.54 & 96.07 & 96.13 & & & \\
\hline
\end{tabular}


Table 5 continued

\begin{tabular}{|c|c|c|c|c|c|c|c|c|c|}
\hline \multirow[t]{2}{*}{ Depth (m) } & \multirow[t]{2}{*}{$\mathrm{Co}\left(\mathrm{mmol}_{+} / \mathrm{dm}^{3}\right)$} & \multirow[t]{2}{*}{$\mathrm{C}\left(\mathrm{mmol}_{+} / \mathrm{dm}^{3}\right)$} & \multicolumn{2}{|c|}{$\mathrm{S}\left(\mathrm{mmol}_{+} / \mathrm{kg}\right)$} & \multicolumn{2}{|l|}{$Q \%$} & \multicolumn{3}{|c|}{ Sorption parameters } \\
\hline & & & DTPA & $\mathrm{AR}$ & DTPA & $\mathrm{AR}$ & Parameter & DTPA & $\mathrm{AR}$ \\
\hline \multirow[t]{10}{*}{$3.3-3.8$} & 0.05 & 0.0008 & 1.30 & 1.77 & 3.95 & 5.31 & $S_{\mathrm{o}}$ & 0.07 & 0.54 \\
\hline & 0.10 & 0.0008 & 2.55 & 3.02 & 7.75 & 9.06 & $V$ & 25 & \\
\hline & 0.15 & 0.0008 & 3.80 & 4.27 & 11.55 & 12.81 & $w$ & 1 & \\
\hline & 0.25 & 0.0048 & 6.20 & 6.67 & 18.85 & 20.01 & $\alpha_{\max }$ & 32.9 & 33.3 \\
\hline & 0.30 & 0.0048 & 7.45 & 7.92 & 22.65 & 23.76 & $b$ & 27.6 & 27.3 \\
\hline & 0.50 & 0.0500 & 11.32 & 11.79 & 34.41 & 35.37 & $\mathrm{MBC}$ & 908.0 & 909.1 \\
\hline & 0.75 & 0.0700 & 17.07 & 17.54 & 51.89 & 52.62 & Corr. coeff. & 0.991 & 0.991 \\
\hline & 1.00 & 0.1300 & 21.82 & 22.29 & 66.33 & 66.87 & & & \\
\hline & 1.50 & 0.3700 & 28.32 & 28.79 & 86.09 & 86.37 & & & \\
\hline & 2.00 & 0.7100 & 32.32 & 32.79 & 98.25 & 98.37 & & & \\
\hline \multirow[t]{10}{*}{$3.8-4.0$} & 0.05 & 0.0004 & 1.31 & 1.74 & 4.17 & 5.48 & $S_{\mathrm{o}}$ & 0.07 & 0.50 \\
\hline & 0.10 & 0.0008 & 2.55 & 2.98 & 8.11 & 9.39 & $V$ & 25 & \\
\hline & 0.15 & 0.0008 & 3.80 & 4.23 & 12.08 & 13.32 & $w$ & 1 & \\
\hline & 0.25 & 0.0120 & 6.02 & 6.45 & 19.14 & 20.32 & $\alpha_{\max }$ & 31.4 & 31.7 \\
\hline & 0.30 & 0.0108 & 7.30 & 7.73 & 23.21 & 24.35 & $b$ & 26.5 & 26.3 \\
\hline & 0.50 & 0.0400 & 11.57 & 12.00 & 36.79 & 37.80 & $\mathrm{MBC}$ & 832.1 & 833.7 \\
\hline & 0.75 & 0.0792 & 16.84 & 17.27 & 53.55 & 54.40 & Corr. coeff. & 0.995 & 0.995 \\
\hline & 1.00 & 0.1320 & 21.77 & 22.20 & 69.23 & 69.93 & & & \\
\hline & 1.50 & 0.4100 & 27.32 & 27.75 & 86.88 & 87.41 & & & \\
\hline & 2.00 & 0.7748 & 30.70 & 31.13 & 97.63 & 98.06 & & & \\
\hline
\end{tabular}

groundwater. The measured actual values of precipitation and air temperature were used to determine the amount of evapotranspiration and to calculate the load of constituents brought to the soils and rocks with wet precipitation. Average annual precipitation, evapotranspiration and temperature in the study period were as follows: $575,442 \mathrm{~mm}$ and $9.4{ }^{\circ} \mathrm{C}$, respectively. These data have allowed for estimating the average $\mathrm{Zn}$ and $\mathrm{Cu}$ pollution loads brought to the soils and rocks, which were $3.27 \mathrm{~kg} / \mathrm{km}^{2} / \mathrm{month}$ for $\mathrm{Cu}$ and $14.88 \mathrm{~kg} / \mathrm{km}^{2} / \mathrm{month}$ for $\mathrm{Zn}$.

The groundwater was dominated by bicarbonate and calcium ions that determined its main hydrochemical type. In addition, depending on the depth of sampling, sodium and sulfate ions significantly affected its hydrochemical type. Relatively significant changes in the proportion of individual ions in the vadose zone, depending on the depth of sampling, indicated substantial impact of the solid phase on groundwater chemical composition. The concentrations of microconstituents in the groundwater tended to decrease with depth, in the case of both copper and zinc. High concentrations of these two elements in rainwater introduced to the soils and rocks significantly decreased with depth (Fig. 7). The average concentration of copper in the precipitation was $0.081 \mathrm{mg} / \mathrm{dm}^{3}$, whereas in the subsurface groundwater it was only $0.054 \mathrm{mg} / \mathrm{dm}^{3}$.
The concentration of $\mathrm{Cu}^{2+}$ decreased with depth, ranging from 0.031 to $0.038 \mathrm{mg} / \mathrm{dm}^{3}$. The average zinc concentration in the precipitation was $0.369 \mathrm{mg} / \mathrm{dm}^{3}$. In the first sampler from the shallowest level, zinc concentration was $0.183 \mathrm{mg} / \mathrm{dm}^{3}$, whereas in the groundwater of the saturation zone it was only $0.059 \mathrm{mg} / \mathrm{dm}^{3}$.

In this section, $\mathrm{Cu}$ and $\mathrm{Zn}$ concentrations in the shallowest zone down to a depth of approximately $0.5 \mathrm{~m}$ were controlled by the chemical composition of precipitation. In the deeper part of the vadose zone, the effect of the solid phase was dominant. In the saturation zone, the effects of water not only infiltrating around the area of the section, but also flowing laterally from other source areas were visible.

\section{Conclusions}

- Chemical analysis of precipitation water and groundwater of shallow circulation zone indicated precipitation as the main contemporary source of copper and zinc in the investigated environment. Average loads of copper and zinc pollution supplied to the substrate in Warsaw region were $\mathrm{Cu}-3.27 \mathrm{~kg} / \mathrm{km}^{2} /$ month and $\mathrm{Zn}-14.88 \mathrm{~kg} / \mathrm{km}^{2} / \mathrm{month}$. 
Table 6 Sorption parameters of zinc, determined for the soils and rocks, for the values of $S_{\mathrm{o}}$ calculated using DTPA and aqua regia methods

\begin{tabular}{|c|c|c|c|c|c|c|c|c|c|}
\hline \multirow[t]{2}{*}{ Depth (m) } & \multirow[t]{2}{*}{$\mathrm{Co}\left(\mathrm{mmol}_{+} / \mathrm{dm}^{3}\right)$} & \multirow[t]{2}{*}{$\mathrm{C}\left(\mathrm{mmol}_{+} / \mathrm{dm}^{3}\right)$} & \multicolumn{2}{|c|}{$\mathrm{S}\left(\mathrm{mmol}_{+} / \mathrm{kg}\right)$} & \multicolumn{2}{|l|}{$Q \%$} & \multicolumn{3}{|c|}{ Sorption parameters } \\
\hline & & & DTPA & $\mathrm{AR}$ & DTPA & $\mathrm{AR}$ & Parameter & DTPA & $\mathrm{AR}$ \\
\hline \multirow[t]{10}{*}{$0.0-0.2$} & 0.20 & 0.0055 & 3.91 & 7.69 & 13.67 & 24.21 & $S_{\mathrm{o}}$ & 0.99 & 4.77 \\
\hline & 0.40 & 0.0051 & 6.91 & 10.69 & 24.20 & 33.69 & $V$ & 15 & \\
\hline & 0.60 & 0.0093 & 9.85 & 13.63 & 34.48 & 42.94 & $W$ & 1 & \\
\hline & 0.80 & 0.0188 & 12.71 & 16.49 & 44.48 & 51.94 & $\alpha_{\max }$ & 28.6 & 31.7 \\
\hline & 1.00 & 0.0176 & 15.73 & 19.51 & 55.04 & 61.44 & $\mathrm{~b}$ & 38.9 & 63.0 \\
\hline & 1.20 & 0.0585 & 18.11 & 21.89 & 63.40 & 68.96 & $\mathrm{MBC}$ & 1112.5 & 1997.1 \\
\hline & 1.40 & 0.0793 & 20.80 & 24.58 & 72.80 & 77.43 & Corr. coeff. & 0.997 & 0.998 \\
\hline & 1.60 & 0.1275 & 23.08 & 26.86 & 80.77 & 84.60 & & & \\
\hline & 1.80 & 0.1889 & 25.16 & 28.94 & 88.05 & 91.15 & & & \\
\hline & 2.00 & 0.2777 & 26.82 & 30.60 & 93.88 & 96.40 & & & \\
\hline \multirow[t]{10}{*}{$0.2-0.7$} & 0.20 & 0.004 & 3.77 & 10.22 & 12.37 & 30.05 & $S_{\mathrm{o}}$ & 1.32 & 7.77 \\
\hline & 0.40 & 0.007 & 6.23 & 12.68 & 20.43 & 37.28 & $V$ & 25 & \\
\hline & 0.60 & 0.014 & 8.65 & 15.10 & 28.37 & 44.39 & $W$ & 2 & \\
\hline & 0.80 & 0.017 & 11.11 & 17.56 & 36.44 & 51.63 & $\alpha_{\max }$ & 30.5 & 34.0 \\
\hline & 1.00 & 0.022 & 13.55 & 20.00 & 44.44 & 58.80 & $b$ & 32.8 & 73.5 \\
\hline & 1.20 & 0.033 & 15.91 & 22.36 & 52.18 & 65.74 & $\mathrm{MBC}$ & 1000.4 & 2499.0 \\
\hline & 1.40 & 0.051 & 18.18 & 24.63 & 59.63 & 72.41 & Corr. coeff. & 0.995 & 0.996 \\
\hline & 1.60 & 0.063 & 20.53 & 26.98 & 67.34 & 79.32 & & & \\
\hline & 1.80 & 0.099 & 22.58 & 29.03 & 74.06 & 85.35 & & & \\
\hline & 2.00 & 0.107 & 24.98 & 31.43 & 81.93 & 92.40 & & & \\
\hline \multirow[t]{10}{*}{$0.7-1.5$} & 0.10 & 0.039 & 3.26 & 4.81 & 14.39 & 20.30 & $S_{\mathrm{o}}$ & 0.205 & 1.76 \\
\hline & 0.15 & 0.050 & 5.21 & 6.76 & 23.01 & 28.53 & $V$ & 50 & \\
\hline & 0.25 & 0.100 & 7.71 & 9.26 & 34.06 & 39.08 & $W$ & 1 & \\
\hline & 0.30 & 0.129 & 8.76 & 10.31 & 38.70 & 43.51 & $\alpha_{\max }$ & 22.6 & 23.7 \\
\hline & 0.50 & 0.255 & 12.46 & 14.01 & 55.05 & 59.12 & $b$ & 5.0 & 6.3 \\
\hline & 0.75 & 0.453 & 15.06 & 16.61 & 66.54 & 70.09 & $\mathrm{MBC}$ & 113.0 & 149.3 \\
\hline & 1.00 & 0.676 & 16.41 & 17.96 & 72.51 & 75.79 & Corr. coeff. & 0.994 & 0.995 \\
\hline & 1.50 & 1.068 & 21.81 & 23.36 & 96.38 & 98.58 & & & \\
\hline & 1.75 & 1.370 & 19.21 & 20.76 & 84.89 & 87.61 & & & \\
\hline & 2.00 & 1.610 & 19.71 & 21.26 & 87.10 & 89.72 & & & \\
\hline \multirow[t]{10}{*}{$1.5-2.8$} & 0.20 & 0.055 & 1.47 & 1.95 & 11.87 & 15.93 & $S_{\mathrm{o}}$ & 0.017 & 0.50 \\
\hline & 0.40 & 0.109 & 2.93 & 3.41 & 23.68 & 27.86 & $V$ & 10 & \\
\hline & 0.60 & 0.185 & 4.17 & 4.65 & 33.71 & 37.99 & $W$ & 1 & \\
\hline & 0.80 & 0.273 & 5.29 & 5.77 & 42.77 & 47.14 & $\alpha_{\max }$ & 12.4 & 12.2 \\
\hline & 1.00 & 0.380 & 6.22 & 6.70 & 50.30 & 54.74 & $b$ & 2.7 & 3.3 \\
\hline & 1.20 & 0.480 & 7.22 & 7.70 & 58.39 & 62.91 & $\mathrm{MBC}$ & 33.5 & 40.3 \\
\hline & 1.40 & 0.636 & 7.66 & 8.14 & 61.95 & 66.50 & Corr. coeff. & 0.998 & 0.999 \\
\hline & 1.60 & 0.777 & 8.25 & 8.73 & 66.72 & 71.32 & & & \\
\hline & 1.80 & 0.920 & 8.82 & 9.30 & 71.33 & 75.98 & & & \\
\hline & 2.00 & 1.080 & 9.22 & 9.70 & 74.57 & 79.25 & & & \\
\hline \multirow[t]{7}{*}{$2.8-3.3$} & 0.20 & 0.091 & 1.099 & 1.26 & 14.24 & 16.48 & $S_{\mathrm{o}}$ & 0.009 & 0.17 \\
\hline & 0.40 & 0.213 & 1.879 & 2.04 & 24.35 & 26.68 & $V$ & 10 & \\
\hline & 0.60 & 0.287 & 3.139 & 3.30 & 40.68 & 43.16 & $W$ & 1 & \\
\hline & 0.80 & 0.492 & 3.089 & 3.25 & 40.03 & 42.51 & $\alpha_{\max }$ & 7.7 & 7.6 \\
\hline & 1.00 & 0.612 & 3.889 & 4.05 & 50.40 & 52.97 & $b$ & 1.7 & 1.9 \\
\hline & 1.20 & 0.786 & 4.149 & 4.31 & 53.77 & 56.37 & $\mathrm{MBC}$ & 13.1 & 14.4 \\
\hline & 1.40 & 0.926 & 4.749 & 4.91 & 61.55 & 64.22 & Corr. coeff. & 0.983 & 0.985 \\
\hline
\end{tabular}


Table 6 continued

\begin{tabular}{|c|c|c|c|c|c|c|c|c|c|}
\hline \multirow[t]{2}{*}{ Depth (m) } & \multirow[t]{2}{*}{$\mathrm{Co}\left(\mathrm{mmol}_{+} / \mathrm{dm}^{3}\right)$} & \multirow[t]{2}{*}{$\mathrm{C}\left(\mathrm{mmol}_{+} / \mathrm{dm}^{3}\right)$} & \multicolumn{2}{|c|}{$\mathrm{S}\left(\mathrm{mmol}_{+} / \mathrm{kg}\right)$} & \multicolumn{2}{|l|}{$Q \%$} & \multicolumn{3}{|c|}{ Sorption parameters } \\
\hline & & & DTPA & $\mathrm{AR}$ & DTPA & AR & Parameter & DTPA & $\mathrm{AR}$ \\
\hline \multirow{12}{*}{$3.3-3.8$} & 1.60 & 1.086 & 5.149 & 5.31 & 66.73 & 69.45 & & & \\
\hline & 1.80 & 1.270 & 5.309 & 5.47 & 68.80 & 71.55 & & & \\
\hline & 2.00 & 1.450 & 5.509 & 5.67 & 71.40 & 74.16 & & & \\
\hline & 0.20 & 0.028 & 0.91 & 2.44 & 14.20 & 32.38 & $S_{\mathrm{o}}$ & 0.053 & 1.58 \\
\hline & 0.40 & 0.052 & 1.79 & 3.32 & 27.88 & 44.06 & $V$ & 10 & \\
\hline & 0.60 & 0.110 & 2.50 & 4.03 & 38.92 & 53.48 & $W$ & 2 & \\
\hline & 0.80 & 0.208 & 3.01 & 4.54 & 46.85 & 60.25 & $\alpha_{\max }$ & 6.4 & 7.5 \\
\hline & 1.00 & 0.284 & 3.63 & 5.16 & 56.49 & 68.47 & $b$ & 5.6 & 10.7 \\
\hline & 1.40 & 0.486 & 4.62 & 6.15 & 71.89 & 81.61 & $\mathrm{MBC}$ & 35.8 & 80.2 \\
\hline & 1.60 & 0.578 & 5.16 & 6.69 & 80.28 & 88.78 & Corr. coeff. & 0.995 & 0.996 \\
\hline & 1.80 & 0.770 & 5.20 & 6.73 & 80.91 & 89.31 & & & \\
\hline & 2.00 & 0.930 & 5.40 & 6.93 & 84.02 & 91.96 & & & \\
\hline \multirow[t]{10}{*}{$3.8-4.0$} & 0.20 & 0.061 & 1.42 & 3.28 & 13.38 & 27.75 & $S_{\mathrm{o}}$ & 0.03 & 1.89 \\
\hline & 0.30 & 0.028 & 2.75 & 4.61 & 25.91 & 39.00 & $V$ & 10 & \\
\hline & 0.50 & 0.109 & 3.94 & 5.80 & 37.11 & 49.07 & $W$ & 1 & \\
\hline & 0.60 & 0.099 & 5.04 & 6.90 & 47.48 & 58.37 & $\alpha_{\max }$ & 10.6 & 11.8 \\
\hline & 0.80 & 0.207 & 5.96 & 7.82 & 56.14 & 66.16 & $b$ & 5.5 & 10.1 \\
\hline & 1.00 & 0.289 & 7.14 & 9.00 & 67.26 & 76.14 & $\mathrm{MBC}$ & 58.3 & 119.2 \\
\hline & 1.20 & 0.440 & 7.63 & 9.49 & 71.87 & 80.29 & Corr. coeff. & 0.974 & 0.996 \\
\hline & 1.50 & 0.710 & 7.93 & 9.79 & 74.70 & 82.82 & & & \\
\hline & 1.75 & 0.848 & 9.05 & 10.91 & 85.25 & 92.30 & & & \\
\hline & 2.00 & 1.095 & 9.08 & 10.94 & 85.53 & 92.55 & & & \\
\hline
\end{tabular}

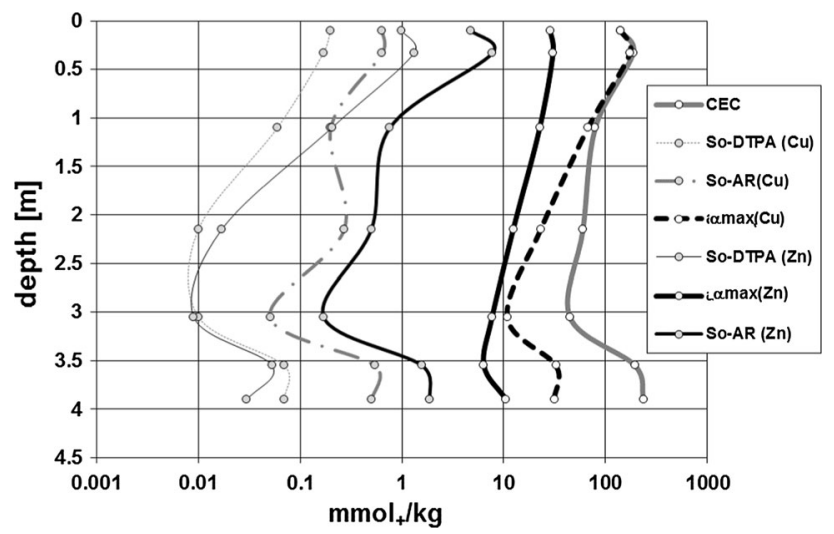

Fig. 6 Changes in the value of maximum sorption $\alpha_{\max }$, initial concentration $S_{\mathrm{o}}$ of copper and zinc, and total cation exchange capacity CEC in the solid phase

- The sorption complex in the investigated profile was formed mainly by the organic matter and amorphous forms of $\mathrm{Fe}, \mathrm{Al}$ and $\mathrm{Mn}$. The highest sorption capacity was found in the subsurface soil and deep clay sediments rich in clay minerals, organic matter and amorphous forms of $\mathrm{Fe}, \mathrm{Al}$ and $\mathrm{Mn}$. The sorption complex was dominated by calcium and magnesium ions, and sodium and potassium ions were subordinate.

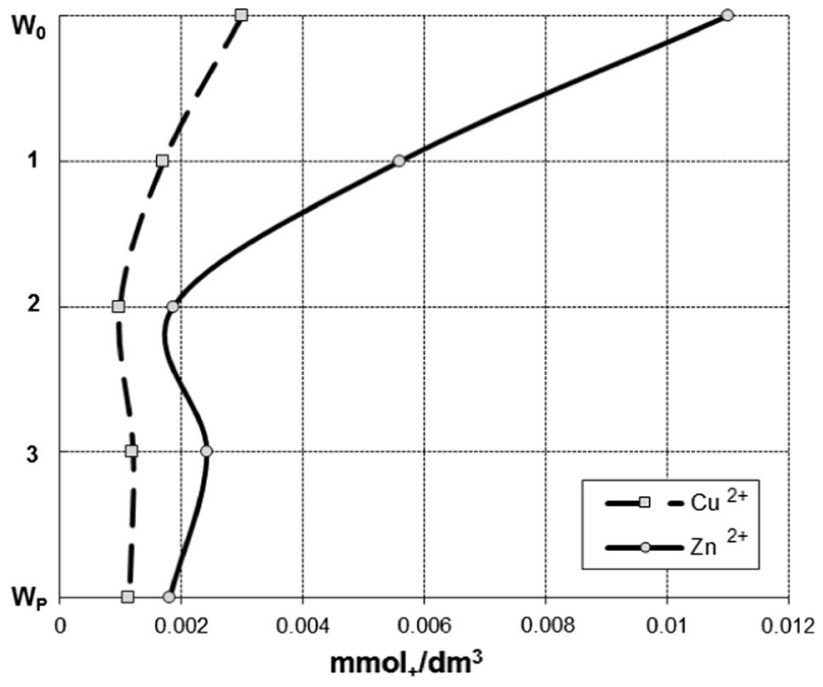

Fig. 7 Vertical changes in copper and zinc concentrations in water, $n=250 . W_{0}$-precipitation, 1, 2, 3-pressure-vacuum samplers (at $0.47,1.43$ and $1.83 \mathrm{~m}$ b.g.l., respectively), $W_{\mathrm{p}}$ - piezometer

- Soil and rock pH ranged from weakly basic in the upper part of the section to weakly acidic in its lower part.

- The study results indicate that the variability of the composition of exchangeable cations was due to 
instability of chemical composition of precipitation. Different activities of $\mathrm{Cu}$ and $\mathrm{Zn}$ in the solution introduced into the rock led to the establishment of new quasi-equilibrium states between the adsorbent and the adsorbate. At very low copper and zinc concentrations in groundwater, zinc was more easily retained in the solid phase and was less easily extracted from it. In contrast, the results of laboratory static batch experiment, utilizing high concentrations of the elements in the solutions, showed their different behaviors. The sorption of copper occurred more easily than of zinc, as evidenced by the study results and the calculated parameters of sorption maximum, binding constant, and degree of surface coverage of the solid phase by adsorbed copper and zinc according to the single Langmuir equation.

- Copper and zinc content in the analyzed groundwater ranged from 0.001 to $0.002 \mathrm{mmol}_{+} / \mathrm{dm}^{3}(\mathrm{Cu})$ and from 0.002 to $0.006 \mathrm{mmol}_{+} / \mathrm{dm}^{3}(\mathrm{Zn})$, with the highest concentrations recorded in the most shallow pressurevacuum samplers. Changes in the concentrations of the studied metals were caused by the impact of the solid phase on the infiltrating water. Considerable amounts of both elements in the precipitation water infiltrating the substrate were found exclusively in the water percolating to a depth of ca. $0.5 \mathrm{~m}$ b.g.l., and below this point their content was clearly reduced.

- Initial content of copper and zinc $\left(S_{\mathrm{o}}\right)$ in the solid phase was determined using two different methods-Lindsay and Norvell's, and aqua regia method. The present stage of the research showed that using methods of variable copper extraction capacity yielded very similar results. As for zinc, it was found that its amount depended on the type of solution-the stronger dissolution capacity of the solution, the higher amount of extracted zinc was obtained. The best results of $S_{\mathrm{o}}$ determination were achieved using the extraction with aqua regia, recommended also as low cost and fairly quick method. Studies on this issue are in progress and involve also other research polygons. Only a comprehensive summary of the results will allow for the statistical documentation of the above-mentioned hypothesis.

Evaluation of the processes determining the changes in copper and zinc concentrations in the hypergenic zone requires further in-depth studies with the use of numerical calculations and thermodynamic models of chemical equilibrium. Further interpretation of the collected material using model calculations will be put forward in the next paper.

Open Access This article is distributed under the terms of the Creative Commons Attribution 4.0 International License (http://crea tivecommons.org/licenses/by/4.0/), which permits unrestricted use, distribution, and reproduction in any medium, provided you give appropriate credit to the original author(s) and the source, provide a link to the Creative Commons license, and indicate if changes were made.

\section{References}

Ajwa HA, Tabatabai MA (1997) Metal-induced sulfate adsorption by soils. Appl Langmuir Equ Soil Sci 162:169-180

Alloway BJ (1995) Heavy metals in soil. Chapman \& Hall, Glasgow

Appelo CAJ, Postma D (1999) Geochemistry, groundwater and pollution. A.A. Balkema, Rotterdam

Arias M, Perez-Novo C, Osorio F, Lopez E (2005) Adsorption and desorption of copper and zinc in the surface layer of acid soils. J Colloid Interface Sci 288:21-29

Augustin PV Jr, Viero AP (2012) Environmental impact and geochemical behavior of soil contaminants from an industrial waste landfill in Southern Brazil. Environ Earth Sci 67:1521-1530

Bojakowska I, Lech D, Jaroszyńska J (2012) Heavy metals in sediments of the Służew Stream in Warsaw (Poland). Górnictwo i Geol 7:71-83 (in Polish)

Covelo EF, Alvarez N, Andrade Couce ML, Vega FA, Marcet P (2004) Zn adsorption by different fractions of Galician soils. J Colloid Interface Sci 280:343-349

Czarnowska K (1999) Heavy metals in plants in Warsaw area. Roczniki Gleboznawcze 50:31-39 (in Polisch)

Deutsch WJ (1997) Groundwater geochemistry. Fundamentals and applications to contamination. Lewis Publication, Boca Raton

Diatta J, Kociałkowski WZ (1998) Adsorption of zinc in some selected soils. Polish J Environ Stud 7:195-200

Fetter CW (1999) Contaminant hydrogeology, 2nd edn. Prentice Hall, Upper Saddle River

Grzebisz W, Kociałkowski WZ, Chudziński B (1997) Copper geochemistry and availability in cultivated soils contaminated by a copper smelter. J Geochem Explor 58:301-307

Kabała C, Chodak T, Szerszen L, Karczewska A, Szopka K, Fratczak U (2009) Factor influencing the concentration of heavy metals in soils of allotment gardens in the city of Wrocław, Poland. Fresenius Environ Bull 18:1118-1124

Kadzikiewicz-Schoeneich M, Małecki JJ (2002) Influence of land use on migration of copper and zinc in groundwaters of shallow circulation. Przegląd Geologiczny 50(10/2):987-995

Kadzikiewicz-Schoeneich M, Małecki JJ, Fic M (2001) Role of meteoric factors in chemical composition of vadose zone waters with special reference to research stations in Warsaw area. Zeitschrift der Bundesanstalt für Alpenlandische Landwirtschaft 9:199-205

Kadzikiewicz-Schoeneich M, Małecki JJ, Gruszczyński T (2005) The process forming the chemical constitution of groundwaters in the investigative profile Warsaw. In: Polish, (Materials of Conference "Present Problems of Hydrogeology")

Kociałkowski WZ, Diatta JB, Grzebisz W (1999) Evaluation of chelating agents as heavy metals extractants in agricultural soils under threat of contamination. Polish J Environ Stud 8:149-154

Langmuir D (1997) Aqueous environmental geochemistry. Prentice Hall, New Jersey

Lead JR, Hamilton-Taylor J, Davison W, Harper M (1999) Trace metal sorption by natural particles and coarse colloids. Geochim Cosmochim Acta 63:1661-1670

Lindsay WL, Norvell WA (1978) Development of a DTPA soil test for zinc, iron, manganese and copper. Soil Sci Soc Am J 42:421-428

Małecki JJ (1995) Role of the zone of aeration in the formation of groundwater chemical composition. Geol Quart 39(4):439-447 
McFarlane DS, Cherry JA, Gillham RW, Sudicky EA (1983) Migration of contaminants in groundwater at a landfill: a case study 1 . Groundwater flow and plume delineation. J Hydrol 63:1-29

McLaren RG, Crawford DV (1973) Studies of soil copper. J Soil Sci $24: 445-452$

McLaren RG, Swift RS, Williams JG (1981) The adsorption of copper by soil materials at low equilibrium solution concentrations. J Soil Sci 32:247-256

McLaren RG, Williams JG, Swift R (1983) Some observations on the desorption and distribution behavior of cooper with soil components. J Soil Sci 34:325-331

Rashad M, Elnaggar E, Assaad FF (2014) Readily dispersible clay and its role in the mobility of transition metals $\mathrm{Cd}^{2+}, \mathrm{Cu}^{2+}$ and
$\mathrm{Zn}^{2+}$ in an alkaline alluvial soil. Environ Earth Sci 71:3855-3864

Ross SM (ed) (1994) Toxic Metals in Soil-plant Systems. Wiley, New York

Stewart BA (ed) (1991) Advances in soil science, vol 16. Springer, New York

Stumm W, Morgan JJ (1981) Aquatic chemistry. Wiley, New York Szwalec A, Mundała P (2012) Contents of $\mathrm{Cd}, \mathrm{Pb}, \mathrm{Zn}$ and $\mathrm{Cu}$ in soil of selected parks of city of Kraków. Ochrona Środowiska i Zasobów Naturalnych 53:63-72 (in Polish)

Tindall JA, Kunkel JR, Anderson DE (1999) Unsaturated zone hydrology for scientists and engineers. Prentice-Hall, Englewood Cliffs 